\title{
COMPUTER SKILLS SURVEY OF GEOGRAPHY TEACHERS IN BOSNIA AND HERZEGOVINA - GENDER, AGE AND REGIONAL DIFFERENCES
}

\author{
DOI: http://dx.doi.org/10.18509/GBP.2020.95 \\ UDC: 373.3.016:91-028.27(497.6) \\ 373.5.016:91-028.27(497.6) \\ 37.011.3-051:91]-028.27(497.6)
}

\author{
Boris Avdić \\ Ranko Mirić \\ Haris Gekić \\ Aida Bidžan-Gekić \\ Department of Geography, Faculty of Science, \\ University of Sarajevo, Bosnia and Herzegovina
}

\begin{abstract}
Computerization of education process is a contemporary trend that is emerging at the global scale, but with substantial regional disparities in the level of its implementation. The present study is aimed at revealing the current situation regarding computer technology use in geographical education in primary and secondary education in Bosnia and Herzegovina through a survey conducted among geography teachers from two typical regions - Canton of Sarajevo with predominantly urban features and Central Bosnia region, where majority of population lives in rural areas. The obtained results suggest that general situation with regard to the level of computer skills identified among geography teachers is satisfying, but that there are still certain disparities across different categories of respondents. It turns out that younger teachers, as well as those from urban region possess a higher level of IT skills and use this technology more frequently for the preparation and implementation of teaching process. At the same time, significant differences regarding the respondents gender have not been found, except in the context of extracurricular activities.
\end{abstract}

Keywords: geography teachers, IT skills, gender differences, age differences, regional differences.

\section{INTRODUCTION}

Computers have become a key tool in geography as a science ever since the era of the quantitative revolution way back in the 1950s and 1960s. However, the application of information technology in geographical education has encountered numerous problems and obstacles in the decades that followed. Early scientific works that were focused on this matter took a rather cautious approach, with the general conclusion that computer technology could be a useful complementary teaching aid tool used in addition to the existing teaching methods, but that it was not supposed to assume a central role as a didactic tool in teaching geography [11]. In the later stages, with the mass proliferation and rapid increase in computer availability, more affirmative attitudes toward the mainstreaming integration of technology into the education system became dominant. Very quickly, ways were found to implement the educational potential of this technology in the domain of geography in light of word processing, databases, telecommunications, 
graphics, drill and practice programs, educational virtual games, digital sources and literature, simulations, multimedia, creativity, and the use of geospatial technology, such as GIS, GPS and remote sensing [3]. Most recent trends also suggest that there is an ever increasing trend of use of virtual reality in the process of geography teaching [13].

The use of all of these forms of geotechnology have resulted in a remarkable diversification of opportunities in the implementation of geographic education at all levels. However, there are numerous differences that have occurred within the teacher and student populations in terms of accepting these fast developing modernization trends. The positive effects of computer use in learning geography lessons are most commonly reported in students [4], but studies conducted with geography teachers have demonstrated generally mixed results. Thus, it often turns out that technological knowledge among teachers is generally not at the level of their content-related and pedagogical knowledge [1]. In their study involving geography teachers from a Turkish city, Şanli et al. [10] have also concluded that the respondents have had insufficient level of skills required to integrate technology into the teaching process. On the other hand, despite the lack of the required level of computer skills, predominantly positive attitudes can usually be recorded among teachers towards information technology, which is clearly pronounced even in poorer regions of the world, such as Africa [7].

Slocum et al. [12] have created a platform to examine the cognitive effects of geovisualization, with individual and group differences being defined as one of the main topics that need to be addressed in future research. Thus, it is highlighted that users of geovisualization should not be treated as a homogeneous group, since there are a number of variables that can potentially influence the attitude that an individual may have towards the educational dimension of computer technology. Such variables include gender, age and regional affiliation. By referring to gender differences among teachers regarding the use of computer technology, Sang et al. [9] conclude that the gap existing in some older studies in favor of male population is reduced over time. The results in terms of age differences suggest that younger teachers tend to have a more positive attitude toward the use of computers and geospatial technologies [6], which does not necessarily mean that they actually use them more often in classroom compared with their older or more experienced colleagues [8]. Regional differences in this context may be well represented by reflecting on a number of urban-rural disparities. Regions with higher levels of urbanization tend to have more favorable socio-economic conditions that are conducive to modernization of the educational process, including the issue of integration of modern technology itself [5].

Since no research has been conducted thus far among the population of geography teachers in Bosnia and Herzegovina about the level of their ICT skills and their attitudes towards the use of computer technology in the teaching process, but also due to the lack of any clear picture about the level of technological modernization of geographic education in this country [2], there is a need to establish the existing facts so that the future strategic steps could then be planned in this particular field. For this purpose, a survey was conducted on a representative sample of teacher population in Bosnia and Herzegovina, whose results were further analyzed by using descriptive and inferential statistical methods. In order to place the results of this research in a wider global context, it would be particularly important to test the following hypotheses:

1. There are significant gender-related differences among geography teachers regarding the respondents' affinity for the use of computer technology in the teaching process; 
2. There are significant age-related differences among geography teachers regarding the respondents' affinity for the use of computer technology in the teaching process; 3. There are significant regional differences among geography teachers regarding the respondents' affinity for the use of computer technology in the teaching process;

\section{SURVEY METODOLOGY}

The survey included a total of 82 geography teachers. These are teachers from Sarajevo Canton (51 teachers) and Central Bosnia Canton (31 teachers), and the sample comprises more than one half the population of geographers in the said cantons. These two cantons were selected on account of the regional disparities that occur between them. On the one hand, Sarajevo Canton is the most densely populated and socio-economically the most developed part of Bosnia and Herzegovina, with an urbanization rate of $86 \%$ according to the last 2013 census. Central Bosnia Canton, on the other hand, is one of the most predominantly rural regions in the country with only $30 \%$ of urban population, and there is no town with larger population than 20 thousand. Thus, despite the geographical proximity of these two cantons, the presented social characteristics indicate their representativeness in terms of the general context of regional differences in Bosnia and Herzegovina. A majority of the surveyed teachers work in primary schools only (78\%). About $55 \%$ of them teach geography only, while the rest are employed as teachers of yet another subject (usually history).

The descriptive results of the survey are reflected primarily in presenting the percentage of frequency of responses received from the respondents, while in the case of multiplechoice questions at the so-called Likert scale, their arithmetic mean $(\bar{x})$ was also calculated. Quantification of the Likert items was carried out in the standardized way, where the most favorable response given in the context of affinity for computer technology scored 5 points, while the least favorable response gained 1 point. A singlepoint interval was established within the range between all five answers on the mentioned scale. The descriptive analysis used in this study serves to provide a general overview of the situation concerning the level of modernization among geography teaching in Bosnia and Herzegovina, including the predispositions for proliferation of GIS-based concept at the primary and secondary education levels. On the other hand, the inferential segment of statistical analysis is aimed at accepting or rejecting the set hypotheses, the purpose of which is to prove the fundamental patterns in the behavior of geography teachers regarding the new teaching aids and methods.

A two-tailed Student's t-test was selected for the inferential part of this statistical analysis, which includes the testing of hypotheses and differences in the responses among different groups of respondents. This study tests the differences between the arithmetic means of the values in the answers provided by the respondents from different groups, which are formed on the basis of gender, age and regional affiliation. Unlike the gender and regional categories, which appear to be obvious, the age categories (younger and older teachers) in this study are formed based on the median age of the respondents (43 years). Thus, the differences based on the existing independent variables can also be tested for individual questions. However, for the purpose of testing the above formulated hypotheses, a further step is taken towards grouping the obtained arithmetic values for individual questions into a new uniform mean arranged by groups of survey questions and given variables. The thus obtained values of the group variables have been subjected to the Student's t-test, where the obtained $p$ value indicates the significance of their differences, according to the standard level $\alpha<.05$. 


\section{RESULTS}

The results obtained in the survey on a selected sample of respondents $(n=82)$ indicate a satisfactory level of application of information technology in the educational process by geography teachers in Bosnia and Herzegovina, although almost two-thirds of them have characterized their own computer skills as average $(\bar{x}=2.85)$. It can be said that they use computer technology relatively often for the purpose class preparation as well as within the class $(\bar{x}=3,72)$. However, the use of computer technology by students in geography classes $(\bar{x}=3,18)$ and in extracurricular geographic activities $(\bar{x}=3,16)$ is at a somewhat lower level. The importance of the Internet has proven to be quite extensive in the context of class preparation $(\bar{x}=4,01)$, but on the other hand it is at a somewhat lower level during the course of work with the students and in dispensing the tasks assigned to students. The highest average response values were achieved in terms of the general attitudes of teachers towards information technology. Approximately, $90 \%$ of the respondents have given a positive answer to the questions of their opinion about potential of ICT to advance teaching $(\bar{x}=4,31)$ and its necessity in modern geographical education $(\bar{x}=4,27)$.

Table 1. Descriptive statistics of the respondents' answers about their attitude towards ICT

\begin{tabular}{|c|c|c|c|c|c|c|c|c|}
\hline Questions & $\mathbf{n}$ & $1(\%)$ & $2(\%)$ & $3(\%)$ & $4(\%)$ & $5(\%)$ & $\overline{\mathbf{x}}$ & $\mathbf{S}$ \\
\hline Perception of personal IT skills & 82 & 15.9 & 1.2 & 65.9 & 15.9 & 1.2 & 2.85 & 0.92 \\
\hline $\begin{array}{l}\text { Using computer technology for } \\
\text { preparation of the teaching process }\end{array}$ & 82 & 0.0 & 2.4 & 32.9 & 37.8 & 26.8 & 3.89 & 0.83 \\
\hline $\begin{array}{l}\text { Using computer technology as part of } \\
\text { the teaching class }\end{array}$ & 82 & 0.0 & 12.2 & 28.0 & 35.4 & 24.4 & 3.72 & 0.97 \\
\hline $\begin{array}{l}\text { Assigning tasks that involve the use } \\
\text { of computers }\end{array}$ & 82 & 1.2 & 13.4 & 52.4 & 31.7 & 1.2 & 3.18 & 0.72 \\
\hline $\begin{array}{l}\text { Using computer technology in } \\
\text { extracurricular activities }\end{array}$ & 82 & 4.9 & 15.9 & 47.6 & 22.0 & 9.8 & 3.16 & 0.97 \\
\hline $\begin{array}{l}\text { Using the Internet for class } \\
\text { preparation }\end{array}$ & 82 & 0.0 & 3.7 & 23.2 & 41.5 & 31.7 & 4.01 & 0.84 \\
\hline $\begin{array}{l}\text { Using the Internet as part of the } \\
\text { teaching class }\end{array}$ & 82 & 4.9 & 14.6 & 37.8 & 31.7 & 11.0 & 3.29 & 1.01 \\
\hline $\begin{array}{l}\text { Assigning homework tasks that } \\
\text { involve the use of the Internet }\end{array}$ & 82 & 1.2 & 12.2 & 54.9 & 26.8 & 4.9 & 3.22 & 0.77 \\
\hline $\begin{array}{l}\text { Attitude towards computer technology } \\
\text { as a means for advancing teaching }\end{array}$ & 81 & 0.0 & 2.5 & 4.9 & 51.9 & 40.7 & 4.31 & 0.68 \\
\hline $\begin{array}{l}\text { Attitude towards the necessity of } \\
\text { introducing ICT in teaching }\end{array}$ & 82 & 0.0 & 2.4 & 8.5 & 48.8 & 40.2 & 4.27 & 0.72 \\
\hline
\end{tabular}

The first tested hypothesis concerns the expectation that male teachers would have a greater affinity for computerization of teaching compared with the female segment of the sample. However, the answers to most questions about the attitudes toward computerization of teaching were relatively surprising, i.e. contrary to the formulated hypothesis. Specifically, the answers to eight out of ten questions provided by women are leading to the conclusion that they rely on computers in their work to a somewhat greater extent, with no statistically significant difference identified in any of these cases. A significant exception appears only with regard to the question about the use of computer technology in extracurricular activities, where a significant difference $(p=.050)$ has been identified that supports the formulated hypothesis. Specifically, it turns out that that men use computers to a much greater extent as a teaching aid in extracurricular activities, despite the fact that the situation is somewhat different in terms of ordinary intracurricular teaching. The total sum of the values obtained from the Likert scale for all answers in this group of questions indicates that no significant difference in attitudes toward 
computerization of teaching has been identified between male and female teachers $(\mathrm{p}=$ .835 , opposite direction), which is why the first hypothesis has been rejected as a result.

Table 2. Gender differences in the respondents' answers about their attitude towards the use of computers

\begin{tabular}{|c|c|c|c|c|c|c|}
\hline \multirow{2}{*}{ Questions } & \multicolumn{2}{|c|}{$\mathbf{N}$} & \multicolumn{2}{|c|}{$\bar{x}$} & \multirow{2}{*}{$\mathbf{p}$} & \multirow{2}{*}{$\begin{array}{c}\text { Statistical } \\
\text { significance }\end{array}$} \\
\hline & $\mathbf{M}$ & $\mathbf{F}$ & $\mathbf{M}$ & $\mathbf{F}$ & & \\
\hline Perception of personal IT skills & 28 & 54 & 2.86 & 2.85 & .983 & \\
\hline $\begin{array}{l}\text { Using computer technology for } \\
\text { preparation of the teaching process }\end{array}$ & 28 & 54 & 3.86 & 3.91 & .808 & \\
\hline $\begin{array}{l}\text { Using computer technology as part of } \\
\text { the teaching class }\end{array}$ & 28 & 54 & 3.68 & 3.74 & .803 & \\
\hline $\begin{array}{l}\text { Assigning tasks that involve the use of } \\
\text { computers }\end{array}$ & 28 & 54 & 3.14 & 3.20 & .716 & \\
\hline $\begin{array}{l}\text { Using computer technology in } \\
\text { extracurricular activities }\end{array}$ & 28 & 54 & 3.43 & 3.02 & .049 & * \\
\hline Using the Internet for class preparation & 28 & 54 & 3.89 & 4.07 & .401 & \\
\hline $\begin{array}{l}\text { Using the Internet as part of the } \\
\text { teaching class }\end{array}$ & 28 & 54 & 3.18 & 3.35 & .442 & \\
\hline $\begin{array}{l}\text { Assigning homework tasks that involve } \\
\text { the use of the Internet }\end{array}$ & 28 & 54 & 3.21 & 3.22 & .965 & \\
\hline $\begin{array}{l}\text { Attitude towards computer technology } \\
\text { as a means for advancing teaching }\end{array}$ & 28 & 53 & 4.25 & 4.34 & .629 & \\
\hline $\begin{array}{l}\text { Attitude towards the necessity of } \\
\text { introducing ICT in teaching }\end{array}$ & 28 & 54 & 4.18 & 4.31 & .489 & \\
\hline HYPOTHESIS 1 & 28 & 54 & 3.58 & 3.60 & .834 & \\
\hline
\end{tabular}

The second hypothesis within this dissertation study tests the differences between the younger and older population groups of geography teachers in terms of their attitudes towards computerization of teaching, where the former group is expected to achieve a significantly higher average scores in the answers to the ten questions asked.

Table 3. Age differences in the respondents' answers about their attitudes toward computer use

\begin{tabular}{lcccccc}
\multicolumn{1}{c}{ Questions } & $\mathbf{Y}$ & $\mathbf{O}$ & $\mathbf{Y}$ & $\mathbf{O}$ & $\mathbf{p}$ & $\begin{array}{l}\text { Statistical } \\
\text { significance }\end{array}$ \\
\hline Perception of personal IT skills & 38 & 38 & $\mathbf{3 . 1 3}$ & 2.61 & .009 & $*$ \\
\hline $\begin{array}{l}\text { Using computer technology for } \\
\text { preparation of the teaching process }\end{array}$ & 38 & 38 & $\mathbf{4 . 1 6}$ & 3.63 & .006 & $*$ \\
\hline $\begin{array}{l}\text { Using computer technology as part of } \\
\text { the teaching class }\end{array}$ & 38 & 38 & $\mathbf{3 . 8 9}$ & 3.50 & .079 & \\
\hline $\begin{array}{l}\text { Assigning tasks that involve the use of } \\
\text { computers }\end{array}$ & 38 & 38 & 3.08 & $\mathbf{3 . 2 9}$ & .207 & \\
\hline $\begin{array}{l}\text { Using computer technology in } \\
\text { extracurricular activities }\end{array}$ & 38 & 38 & 3.13 & $\mathbf{3 . 2 1}$ & .729 & $*$ \\
\hline Using the Internet for class preparation & 38 & 38 & $\mathbf{4 . 2 6}$ & 3.76 & .007 & $*$ \\
\hline $\begin{array}{l}\text { Using the Internet as part of the } \\
\text { teaching class }\end{array}$ & 38 & 38 & $\mathbf{3 . 5 3}$ & 3.05 & .036 & $*$ \\
\hline $\begin{array}{l}\text { Assigning homework tasks that involve } \\
\text { the use of the Internet }\end{array}$ & 38 & 38 & $\mathbf{3 . 2 9}$ & 3.16 & .463 & \\
\hline $\begin{array}{l}\text { Attitude towards computer technology } \\
\text { as a means for advancing teaching }\end{array}$ & 38 & 37 & $\mathbf{4 . 4 7}$ & 4.16 & .034 & $*$ \\
\hline $\begin{array}{l}\text { Attitude towards the necessity of } \\
\text { introducing ICT in teaching }\end{array}$ & 38 & 38 & $\mathbf{4 . 3 7}$ & 4.16 & .179 & $*$ \\
\hline HYPOTHESIS 2 & 38 & 38 & $\mathbf{3 . 7 3}$ & 3.45 & .024 & $*$ \\
\hline
\end{tabular}

The results show that, quite expectedly, the younger group of teachers have provided more favorable answers to as many as eight questions in this segment of the survey in comparision to their older colleagues. A significant difference can be identified in the answers to five questions. It is particularly important that the younger teachers have rated 
their own level of IT skills as significantly better compared with older respondents $(\mathrm{p}=$ $.009)$. In addition, they are more likely to use computers $(\mathrm{p}=.006)$ and the Internet $(\mathrm{p}=$ .007) for class preparation. As far as the implementation of the teaching process is concerned, younger teachers are more likely to reach out to the Internet during the classes $(\mathrm{p}=.036)$. Based on the results obtained, it can also be said that they seem to agree to a much greater extent that computer technology can advance geography teaching $(\mathrm{p}=.034)$. The older group of teachers has achieved a higher score of answers only in terms of assigning tasks that involve the use of computer technology and its use in extracurricular activities, although the level of statistical difference has been identified as quite insufficient to support the findings of an actual difference in that regard. The tested total score of the Likert scale responses for these two groups of respondents indicates that the second hypothesis about the significantly higher preferences among younger teachers towards the use of computer technology in teaching has been confirmed in this study ( $\mathrm{p}$ $=.024)$.

Table 4. Regional differences in the respondents' answers about their attitude toward computer use

\begin{tabular}{llccccc}
\multicolumn{1}{c}{ Questions } & $\mathbf{U}$ & $\mathbf{R}$ & $\mathbf{U}$ & $\mathbf{R}$ & $\mathbf{P}$ & $\begin{array}{c}\text { Statistical } \\
\text { significance }\end{array}$ \\
\hline Perception of personal IT skills & 51 & 31 & $\mathbf{3 . 0 6}$ & 2.52 & .010 & $*$ \\
\hline $\begin{array}{l}\text { Using computer technology for } \\
\text { preparation of the teaching process }\end{array}$ & 51 & 31 & $\mathbf{4 . 2 4}$ & 3.32 & .000 & $*$ \\
\hline $\begin{array}{l}\text { Using computer technology as part of } \\
\text { the teaching class }\end{array}$ & 51 & 31 & $\mathbf{4 . 1 4}$ & 3.03 & .000 & $*$ \\
\hline $\begin{array}{l}\text { Assigning tasks that involve the use of } \\
\text { computers }\end{array}$ & 51 & 31 & $\mathbf{3 . 3 9}$ & 2.84 & .000 & $*$ \\
\hline $\begin{array}{l}\text { Using computer technology in } \\
\text { extracurricular activities }\end{array}$ & 51 & 31 & $\mathbf{3 . 3 7}$ & 2.81 & .008 & $*$ \\
\hline Using the Internet for class preparation & 51 & 31 & $\mathbf{4 . 1 6}$ & 3.77 & .052 & \\
\hline $\begin{array}{l}\text { Using the Internet as part of the } \\
\text { teaching class }\end{array}$ & 51 & 31 & $\mathbf{3 . 5 5}$ & 2.87 & .004 & $*$ \\
\hline $\begin{array}{l}\text { Assigning homework tasks that involve } \\
\text { the use of the Internet }\end{array}$ & 51 & 31 & $\mathbf{3 . 3 7}$ & 2.97 & .018 & $*$ \\
\hline $\begin{array}{l}\text { Attitude towards computer technology } \\
\text { as a means for advancing teaching }\end{array}$ & 51 & 31 & 4.20 & $\mathbf{4 . 5 0}$ & .040 & \\
\hline $\begin{array}{l}\text { Attitude towards the necessity of } \\
\text { introducing computer technology in } \\
\text { teaching }\end{array}$ & 51 & 30 & 4.18 & $\mathbf{4 . 4 2}$ & .121 & $*$ \\
\hline HYPOTHESIS 3 & 51 & 31 & $\mathbf{3 . 7 6}$ & 3.30 & .000 & $*$ \\
\hline
\end{tabular}

Many of the results obtained in this study are in line with expectations, i.e. they can be explained by the factors presented at an earlier point in this paper. This is of particular relevance for computerization of the teaching process, since in seven out of ten questions in this survey segment, teachers from the Sarajevo region have provided a considerably higher number of more favorable answers, specifically about their own level of IT skills $(\mathrm{p}=.010)$, the use of computer technology for class preparation $(\mathrm{p}=.000)$ and for conducting classes $(\mathrm{p}=.000)$, then for enabling students to use computer technology during the classes $(\mathrm{p}=.000)$ and in extracurricular activities $(\mathrm{p}=.008)$, and for assigning homework tasks that involve the use of computers $(p=.000)$ and the Internet $(p=.018)$. Still, the answers to two remaining questions are quite surprising. Specifically, teachers from the Central Bosnia region have felt to a much greater extent that computer technology could advance geography teaching $(\mathrm{p}=.040)$, while no sufficiently large difference has been identified between the two groups $(p=.121)$ in the attitudes about the necessity of their use. Nonetheless, the third hypothesis of a significantly higher affinity 
among the geography teachers from the Sarajevo region towards the use of computer technology in teaching has been strongly confirmed in this study $(\mathrm{p}=.000)$.

\section{CONCLUSIONS}

Two out of the three formulated general hypotheses have been confirmed through this research. The methods of inferential statistics used on the selected samples reveals that the younger group of teachers is more inclined to use computers in the classroom. The same can be said for the teachers from Sarajevo Canton (as an urban region), compared with those who do their jobs in the Central Bosnia Canton (as a predominantly rural region). The fact that both of these hypotheses have been confirmed can be easily accounted for through an overall understanding of the general social trends emerging nowadays, where younger and urban populations are significantly more exposed to the impact of modern technological breakthroughs. However, an unexpected anomaly has also been observed through this segment of research. Specifically, the teachers in the urban region, who tend to use information technology more often, in general, have expressed a less positive view of the benefits that this technology brings to education compared with their counterparts who work in rural areas. In addition, it is worth noting that no gender differences have been identified between the teachers in this respect, except in the context of the use of computer technology in extracurricular activities, which is much more preferred by men among the surveyed teachers.

The results obtained in this survey can also be interpreted from the perspective of the current socio-economic conditions in Bosnia and Herzegovina as a transitional state, but their primary purpose is to be used as a helpful tool in the creation of a future educational strategy. The identified regional disparities suggest the need to make the computer technology much more readily accessible to schools in predominantly rural areas of the country, which can be done by making more valuable financial investments into this technology and delivering technological training to teachers. The need for specific activities undertaken to enable professional development of the older teaching population is particularly pronounced in this regard. On the other hand, the fact that more technologically advanced teachers from the urban region have achieved a lower score with regard to using computer technology as a teaching aid factor to improve teaching, compared to their rural counterparts, brings about certain indications that it would be appropriate to redefine its role in the teaching process and devise new methods for its use. Thus, it has become quite evident that the computerization of geographic education per se does not necessarily go hand in hand with progress made in terms of its quality. In order to get a clearer picture of teachers' attitudes towards computer technology across Bosnia and Herzegovina, it would be necessary to extend the scope of research primarily in terms of extending the surveyed area covered by it, since this particular study is restricted to two typological regions only.

\section{REFERENCES}

[1] Doering, A., Koseoglu, S., Scharber, C., Henrickson, J. \& Lanegran, D. Technology Integration in K-12 Geography Education Using TPACK as a Conceptual Model. Journal of Geography, vol. 113(6), pp 223-237, 2014.

[2] Drešković, N. \& Avdić, B. Didactic aspects of GIS application in geographic school education. Geographical Review, vol. 38, pp 133-144, 2017. 
[3] Fitzpatrick, C. Teaching Geography With Computers. Journal of Geography, vol. 92(4), pp 156-159, 1993.

[4] Garyfallidou, D. M. \& Ioannidis, G. S. Teaching geography with the use of ICT. International Conference on Interactive Mobile Communication Technologies and Learning, Greece, 2004, pp 57-63.

[5] Howley, A., Wood, L. \& Hough, B. Rural Elementary School Teachers' Technology Integration. Journal of Research in Rural Education, vol. 26(9), pp 1-13, 2011.

[6] Kim, M., Bednarz, R. \& Lee, S. I. GIS Education for Teachers in South Korea: Who Participates and Why? Journal of the Korean Geographical Society, vol. 46(3), pp 382-395, 2011.

[7] Osodo, J., Indoshi, F. C. \& Ongati, O. Attitudes of students and teachers towards use of computer technology in Geography education. Educational Research, vol. 1(5), pp 145-149, 2010.

[8] Russell, M., Bebell, D., O’Dwyer, L. \& O’Connor, K. Examining Teacher Technology Use: Implications for Preservice and Inservice Teacher Preparation. Journal of Teacher Education, vol. 54(4), pp 297-310, 2003.

[9] Sang, G., Valcke, M., Van Braak, J. \& Tondeur, J. Student teachers' thinking processes and ICT integration: Predictors of prospective teaching behaviors with educational technology. Computers \& Education, vol. 54(1), pp 103-112, 2010.

[10] Şanli, C., Sezer, A. \& Pinar, A. Perceptions of Geography Teachers to Integrating Technology to Teaching and their Practices. Review of International Geographical Education Online (RIGEO), vol. 6(3), pp 234-252, 2016.

[11] Shepherd, I. D. H. Teaching Geography with the Computer: possibilities and problems. Journal of Geography in Higher Education, vol. 9(1), pp 3-23, 1985.

[12] Slocum, T. A., Blok, C., Jiang, B., Koussoulakou, A., Montello, D. R., Fuhrmann, S. \& Hedley, N. R. Cognitive and Usability Issues in Geovisualization. Cartography and geographic information science, vol. 28(1), pp 61-75, 2001.

[13] Stojšić, I., Ivkov Džigurski, A., Maričić, O., Ivanović Bibić, Lj. \& Đukičin Vučković, S. Possible Application of Virtual Reality in Geography Teaching. Journal of Subject Didactics, vol. 1(2), pp 83-96, 2016. 